\title{
Prototype Smart Home Pengendali Lampu Dan Gerbang Otomatis Berbasis IoT Pada Sekolah Islam Pelita Insan Menggunakan Microcontroller Nodemcu V3
}

\author{
Wiyanto $^{1)}$ dan Yayan Oktavianti ${ }^{2)}$ \\ *Jurusan Teknik Informatika, Fakultas Teknik, Universitas Pelita Bangsa, Jl. Inspeksi Kalimalang No.09 Cibatu, \\ Cikarang Pusat, Bekasi, Jawa Barat 17530, Indonesia \\ 1) wiyanto@pelitabangsa.ac.id \\ 2) oktavianiyayan06@gmail.com
}

\begin{abstract}
Abstrak. Perkembangan teknologi pada jaman ini merambah ke dalam berbagai kehidupan manusia, seperti halnya pengembangan rumah dengan smart home yang dapat memberikan kemudahan, kenyamanan, keamanan dan efisien untuk pengguna. Teknologi Internet of Things (IoT) dapat dimanfaatkan pada rumah pintar (Smart Home) untuk mengendalikan berbagai peralatan elektronik seperti lampu, AC, pintu gerbang rumah dan yang lainnya. Penelitian ini bermaksud merancang sebuah prototipe sistem smart home pengendali lampu dan gerbang otomatis berbasis IoT menggunakan microcontroller NodeMCU yang bertujuan untuk menghemat listrik, mengefektifkan dan mengefisienkan, serta mempermudah penjaga dan pengelola sekolah untuk menghidupkan dan mematikan lampu serta mengendalikan pintu gerbang secara otomatis melalui google assistant. Hasil penelitian ini yaitu berupa prototype sistem pengendali lampu dan gerbang otomatis menggunakan aplikasi google assistant berbasis IoT dengan menggunakan microcontroller NodeMCU v3. Dari penelitian ini dapat diambil kesimpulan dengan adanya prototype sistem pengendali lampu dan gerbang otomatis menggunakan aplikasi google assistant dengan cara memberikan perintah ke google assistant yang terkoneksi ke microcontroller NodeMCU V3, diharapkan dapat mempermudah pengelola dan penjaga sekolah untuk mengefektifkan dan mengefisienkan pengendalian lampu atau gerbang menggunakan aplikasi google assistant serta dapat mempermudah penjaga dan pengelola sekolah untuk menjaga keamanan sekolah dengan teknologi IoT.
\end{abstract}

Kata kunci: Internet of Things, Smart Home, NodeMCU, Google Assistant.

\begin{abstract}
The development of technology at this time has penetrated various human lives, such as the addition of home developments with smart homes that can provide convenience, comfort, safety, and efficiency for users. Internet of Things (IoT) technology can be used in smart homes (Smart Home) to control various electronic equipment such as lights, air conditioners, home gates, and others. This study designed a prototype of a smart home system for lighting and gate controllers based on IoT using a NodeMCU microcontroller which aims to increase electricity, make it more effective and efficient, and make it easier for school guards and managers to turn on and turn off lights and gate control doors automatically through google assistant. The results of his research are a prototype of an automatic light and gate control system using a google assistant application based on the IoT using a NodeMCU v3 microcontroller. From this research, the conclusion can be drawn with the existence of a prototype of an automatic light and gate control system using the google assistant application by giving commands to the google assistant connected to the NodeMCU V3 microcontroller, which is expected to make it easier for school managers and guards to make effective and efficient control of lights or gates using the application google assistant and can make it easier for school guards and managers to maintain school security with IoT technology.
\end{abstract}

Keywords: Internet of Things, Smart Home, NodeMCU, Google Assistant.

\section{Pendahuluan}

Perkembangan teknologi pada jaman ini sudah merambah ke dalam kehidupan manusia, seperti halnya pengembangan rumah dengan smart home yang dapat memberikan kemudahan, kenyamanan, keamanan dan efisien untuk pengguna. Internet of
Things (IoT) dapat dimanfaatkan pada smart home untuk mengendalikan peralatan elektronik seperti lampu dan gerbang sekolah. Dengan kemajuan teknologi yang terus melaju begitu cepat, keilmuan ini harus segera dipelajari serta diterapkan dalam kehidupan sehari-hari. Suatu contoh adalah 
perkembangan teknologi smart home yang dapat dimanfaatkan dari adanya koneksi internet yang sudah menyebar keseluruh dunia. Pada teknologi smart home yang dapat mengakses mesin-mesin, peralatan elektronik seperti lampu, AC, pintu gerbang sekolah dan lain sebagainya yang dioperasikan secara cara online melalui aplikasi google assistant. Sehingga, dapat memudahkan pengguna mengendalikan peralatan elektoronik seperti lampu atau pintu gerbang dengan mudah.

Adapun penerapan smart home dapat membantu pekerjaan manusia, pekerjaan tersebut dapat dilakukan dengan mudah, cepat dan praktis dengan menghemat banyak waktu. Dalam hal ini Sekolah Islam Pelita Insan dalam mengontrol lampu dan pintu gerbang masih dengan cara konvensional yaitu dengan cara menyalakan melalui saklar dan buka tutup pintu gerbang secara manual, petugas harus menghidupkan dan mematikan lampu dan perangkat elektronik lainnya secara manual yang terhubung ke perangkat listrik tersebut. Dari studi kasus dilapangan, terdapat beberapa perangkat elektroknik dam listrik, seperti lampu dan yang lainnya dijumpai masih menyala ketika sudah tidak digunakan, hal ini disebabkan oleh kelalaian pengguna untuk mematikan perangkat elektronik dan lampu-lampu tersebut. Jika terdapat jumlah perangkat elektronik dan listrik yang berada disekolah banyak, maka memerlukan waktu dalam mengendalikannya. Penggunaan energi listrik dari perangkat-perangkat tersebut tidak efisien dan pengendara mobil atau motor ketika akan masuk atau keluar rumah seseorang harus membuka gerbang rumah terlebih dahulu dan menutupnya kembal hal ini cukup menyita waktu pengendara tersebut, terlebih jika dia sedang terburu-buru tersebut maka akan sangat menyulitkan dan sangat menyita waktu pengendara mobil atau motor yang ingin keluar masuk rumah. Untuk membuatnya lebih efisien sebaiknya, pengendara mobil atau motor tidak perlu turun dari kendaraannya tersebut untuk membuka atau menutup pintu gerbang.

Penelitian yang relevan sebelumnya yaitu: dikutip dari (Satriadi, Wahyudi, \& Christiyono, 2019) didalam penelitiannya yang berjudul "Perancangan Home Automation Berbasis NodeMCU'. Dalam penelitian ini membahas perancangan home automation berbasis NodeMCU yang dapat mengontrol lampu, kipas, AC yang disimbolkan oleh tiga buah lampu, dan juga pintu pagar yang dikendalikan oleh Motor DC melalui web server. Web server menggunakan situs hosting jogjahost.com dan menggunakan bahasa pemrograman web PHP dan menggunakan sinyal HSPA+ dan 4G sebagai koneksi internet pada NodeMCU ESP-12E. Tujuan penelitian ini lebih memudahkan manusia untuk mengakses perangkat-perangkat elektronik melalui jaringan internet. Ketika sedang dalam bepergian, terkadang seseorang lupa untuk mematikan peralatan elektronik seperti lampu, kipas angin, dan air conditioner $(A C)$.
Penelitian ini bertujuan untuk dapat merancang suatu prototype smart home yang bertujuan untuk menghemat listrik, mempermudah petugas penjaga dan pengelola sekolah untuk menghidupkan lampu dan mengendalikan gerbang secara otomatis melalui google assistant dengan rancangan Prototype Smart Home Pengendali Lampu Dan Gerbang Otomatis Berbasis IoT Pada Sekolah Islam Pelita Insan Menggunakan Micro Controller Nodemcu V3.

\section{Bahan dan Metode: Model Prototyping}

Menurut McLeod (Mcleod, 2008), prototipe didefinisikan sebagai alat yang memberikan ide bagi pembuat maupun pemakai potensial tentang cara sistem berfungsi dalam bentuk lengkapnya, dan proses untuk menghasilkan sebuah prototype disebut prototyping. Penggunaan pada prototype ini dari aspek-aspek perangkat lunak tersebut yang akan berguna dan dimanfaatkan oleh pelanggan atau pemakai.

Berikut merupakan Siklus Pengembangan Model Prototyping :

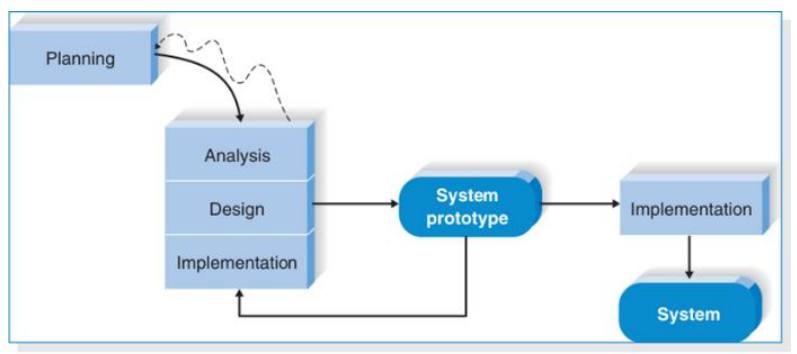

Gambar 1. Siklus Pengembangan Model Prototyping

Adapun cakupan dari model prototyping ialah sebagai berikut :

1. Mendefinisikan objektif secara keseluruhan dan mengidentifikasi kebutuhan yang sudah diketahui.

2. Melakukan perancangan secara cepat sebagai dasar untuk membuat prototype.

3. Menguji coba dan mengevaluasi prototype dan kemudian melakukan penambahan dan perbaikanperbaikan terhadap prototype yang sudah dibuat.

\section{Definisi Smart Home}

Smart Home menurut (Briere \& Hurley, 2007) adalah Rumah pintar adalah rumah yang harmonis, kumpulan perangkat dan kemampuan yang bekerja sesuai dengan Zen of Home Networking. Kuncinya adalah mendapatkan informasi ke dan dari masingmasing perangkat ini. Itu membutuhkan jaringan.

Elemen di dalam rumah yang dibutuhkan untuk menjadi "smart" yaitu:

1. Jaringan internal, berisi perkawatan, kabel, nirkabel.

2. Kontrol cerdas, sebagai gateway untuk mengatur system. 
3. Otomatisasi rumah, sebagai produk dimana rumah dan koneksi ke layanan dan sistem diluar rumah.

\section{Definisi Smart Phone}

Dikutip dari jurnal (Arifin, 2014), Secara harfiah artinya telepon pintar, yaitu telepon seluler yang memiliki kemampuan seperti komputer walaupun terbatas. Selain hal itu, smartphone juga mendukung email dan organiizer. Fitur lain pada sebuah smartphone adalah mempunyai suatu kemampuan untuk ditambahkan aplikasi-aplikasi baru. Penambahan aplikasi pada smartphone dapat dibuat oleh seorang programmer ataupun dari pihak ke tiga, aplikasi-aplikasi itu tidak hanya dibuat produsen pembuat piranti tersebut.

\section{Definisi Internet of Things (IoT)}

Internet of Things (IoT) menurut (Hassan, Khan, \& Madani, 2018) ialah Infrastruktur global untuk informasi kepada masyarakat, memungkinkan layanan lanjutan dengan menghubungkan hal-hal (fisik dan virtual) berdasarkan interoperable yang ada dan berkembang pada teknologi informasi dan komunikasi. IoT merupakan sebuah konsep yang bertujuan untuk memperluas manfaat dari konektivitas menggunakan internet yang tersambung secara terusmenerus yang memungkinkan kita dapat menghubungkan antara mesin, peralatan, dan benda fisik lainnya dengan suatu sensor untuk memperoleh data dan mengelola suatu kinerja, sehingga memungkinkan mesin ataupun peralatan yang lainnya dapat saling berkolaborasi dan bahkan bertindak berdasarkan informasi diperoleh.

\section{Definisi Microcontroller}

Dikutip dari pernyataan (Sasongko, 2013), microcontroller adalah suatu central processing unit $(C P U)$ yang disertai dengan memori serta sarana input-output dan dibuat dalam bentuk chip. CPU ini terdiri dari dua bagian yaitu yang pertama adalah unit pengendali dan yang ke dua adalah unit aritmatika dan logika.

Tabel 1. Kelebihan Microcontroller

\begin{tabular}{|c|c|}
\hline No & Kelebihan Microcontroller \\
\hline 1. & $\begin{array}{l}\text { Penggerak pada mikrokontroler menggunakan } \\
\text { Bahasa pemograman assembly dengan } \\
\text { berpatokan pada kaidah digital dasar sehingga } \\
\text { pengoprasian sistem menjadi sangat mudah } \\
\text { dikerjakan sesuai dengan logika sistem (Bahasa } \\
\text { assembly ini mudah dimengerti karena } \\
\text { parameter input dan output langsung bisa di } \\
\text { akses tanpa menggunakan banyak syarat } \\
\text { perintah). }\end{array}$ \\
\hline
\end{tabular}

2. Mikrokontroler tersusun dalam satu chip dimana prosesor, memori, dan $I / O$ terintregrasi menjadi satu kesatuan control sistem sehingga mikrokontroler dapat dikatakan sebagai computer mini yang dapat bekerja secara inovatif sesuai dengan kebutuhan sistem.

3. Sistem running bersifat berdiri sendiri tanpa tergantung dengan computer sedangkan parameter computer hanya digunkan untuk download perintah instruksi atau program.

4. Pada mikrokontroler tersedia fasilitas tambahan untuk pengembangan memori dan $I / O$ yang disesuaikan dengan kebutuhan sistem.

5. Harga untuk memperoleh alat ini lebih murah dan mudah di dapat.

\section{Definisi NodeMCU 8266}

Dikutip dari pernyataan (Nussey, 2013), NodeMCU pada dasarnya adalah pengembangan dari ESP 8266 dengan firmware berbasis e-Lua. Pada NodeMcu dilengkapi dengan micro usb port yang berfungsi untuk pemorgaman maupun power supply. Dengan penggunaan NodeMCU 8266 sangat tepat jika digunakan pada rancangan smart home berbasis IoT. Selain itu juga pada NodeMCU di lengkapi dengan tombol push button yaitu tombol reset dan flash.

\section{Definisi Unified Modelling Language (UML)}

Definisi mengenai UML menurut (Booch, 2013), Unified Modelling Language (UML) adalah bahasa yang di gunakan untuk pemodelan umum untuk melakukan spesifikasi, visualisasi, kontruksi, dan dokumentasi artifact bagian dari informasi yang digunakan dalam proses pembuatan perangkat lunak. Dari artifact tersebut dapat berupa model, deskripsi atau perangkat lunak dari sebuah perancangan sistem perangkat lunak.

\section{Hasil dan Pembahasan Metodologi Penelitian}

Penelitian ini menggunakan metode Prototype dan tahapan penelitian diawali dengan melakukan penentuan komponen yang akan digunakan, membuat prototype hardware, dan melakukan pengujian, yaitu dengan tahapan sebagai berikut: 


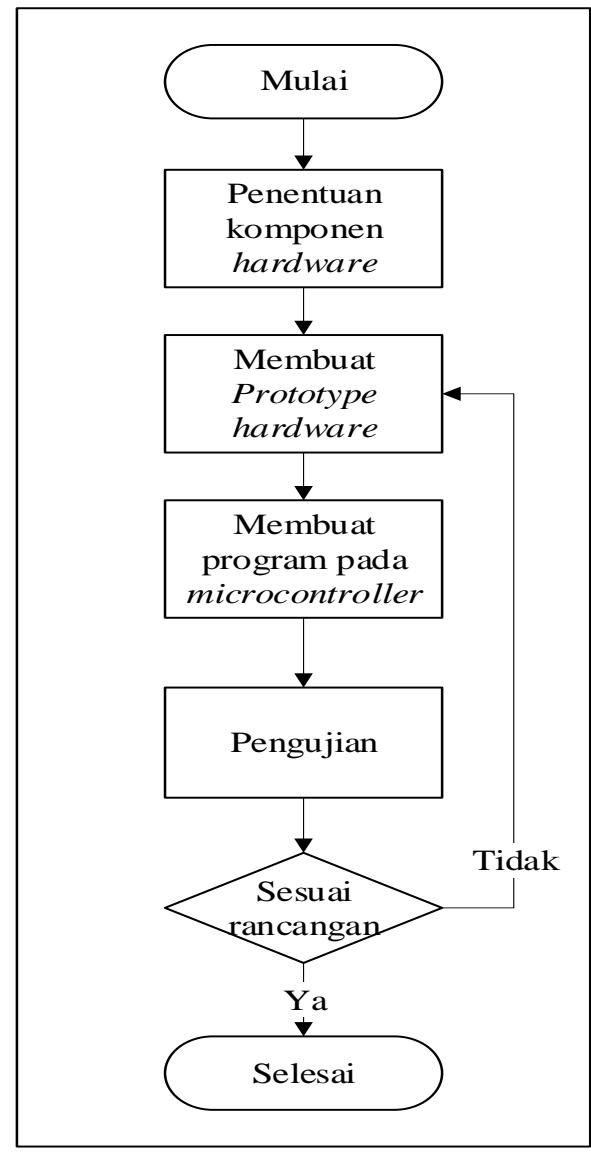

Gambar 2. Tahapan Penelitian

\section{Model Prototyping}

\section{Planning}

Mendefinisikan objektif secara keseluruhan dan mengidentifikasi kebutuhan yang sudah diketahui, diantaranya:

1. Spesifikasi Hardware

Berikut adalah perangkat keras yang digunakan untuk merancang sistem:

- PC/Labtop

- NodeMCU V3

- Relay 4 chanel

- Protoboard

- Servo Motor

- LED

- Kabel Jumper

- Kabel USB

- Smartphone

- Adaptor 12V

2. Spesifikasi Software

Software yang digunakan untuk merancang sistem smart home:

- Sistem Operasi Windows

- Arduino IDE

- Google Assistant

3. Bahasa pemrograman

Adapun Bahasa pemrograman yang digunakan dalam merancang sistem kendali lampu dan gerbang otomatis yaitu menggunakan Bahasa
Pemrograman C\# untuk membuat program pada Microcontroller.

\section{Analysis}

Analisa kebutuhan sistem yang diperlukan dalam merancang prototype ini ialah berupa :

1. Use Case Diagram

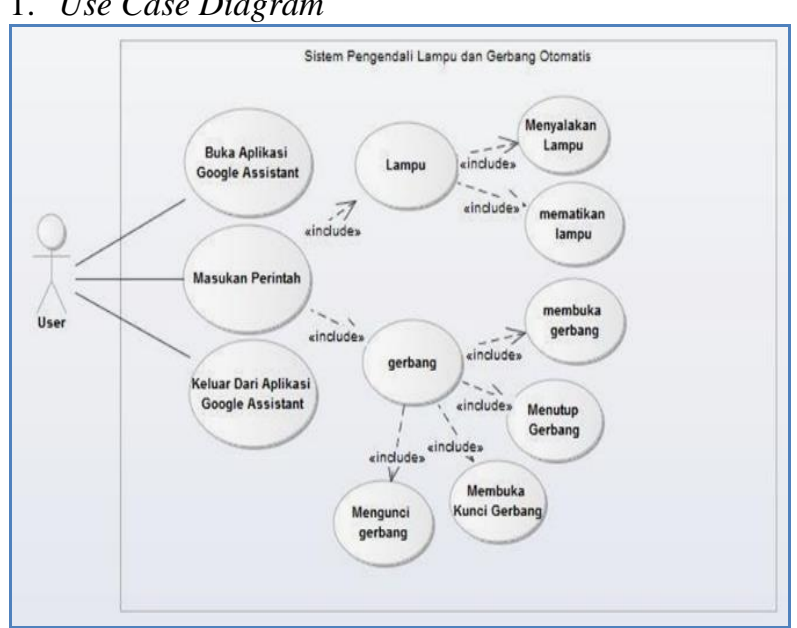

Gambar 3. Use Case Diagram

Berdasarkan use case diagram diatas maka urutan langkah-langkah yang dilakukan actor terhadap sistem smart home pengendali lampu dan gerbang otomatis adalah:

a. User membuka aplikasi google assistant untuk memberikan perintah.

b. Lalu user memberikan perintah.

c. Jika user sudah memberikan perintah yang diinginkan maka user dapat menutup atau keluar aplikasi google assistant jika memang sudah tidak digunakan.

\section{Activity Diagram}

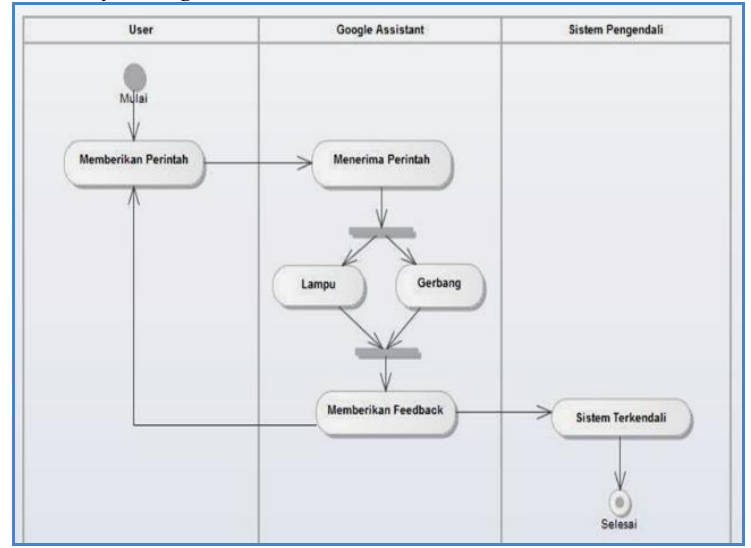

Gambar 4. Activity Diagram Sistem Kendali Smartphone

Berikut Activity Diagram sistem kendali smart home yang dilakukan oleh user:

a. User memberikan perintah.

b. Google Assistant menerima perintah dari user dan memberikan feedback kepada user. 
c. Sistem pengendali Smart home terkendali.

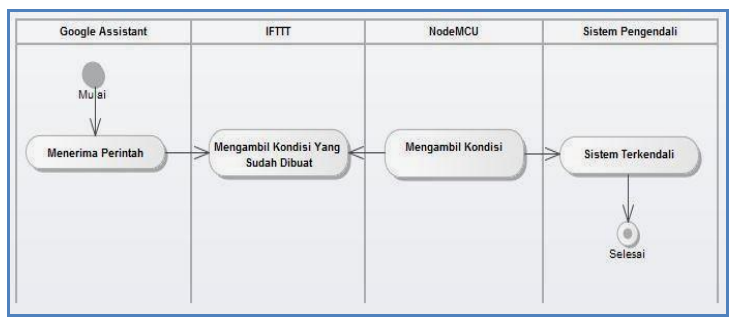

Gambar 5. Activity Diagram Control System

Berikut Activity Diagram Control System:

a. Setelah google assistant menerima perintah dari user.

b. IFTTT akan menggambil kondisi yang sudah dibuat sebelum nya.

c. Lalu NodeMCU akan menggambil kondisi di IFTTT, dan sistem pengendali smart home terkendali.

\section{Squence Diagram}

Squence Diagram mendeskripsikan interaksi antar fungsi suatu kelas maupun dengan fungsi pada kelas yang berbeda. Diagram Squence mempermudah mengetahui fungsi-fungsi dalam suatu kelas. Gambar berikut merupakan Squence Diagram sistem smart home pengendali lampu dan gerbang otomatis

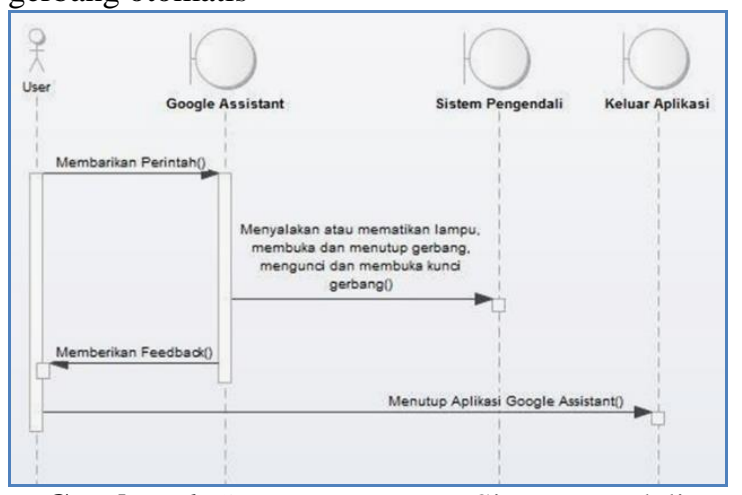

Gambar 6. Squence Diagram Sistem Kendali Smart Home

Squence Diagram sistem kendali smart home yang dilakukan oleh user:

a. User memberikan perintah.

b. Google Assistant menerima perintah dari user dan memberikan feedback

c. kepada user.

d. Sistem pengendali smart home terkendali.

e. User keluar dari aplikasi google assistant.

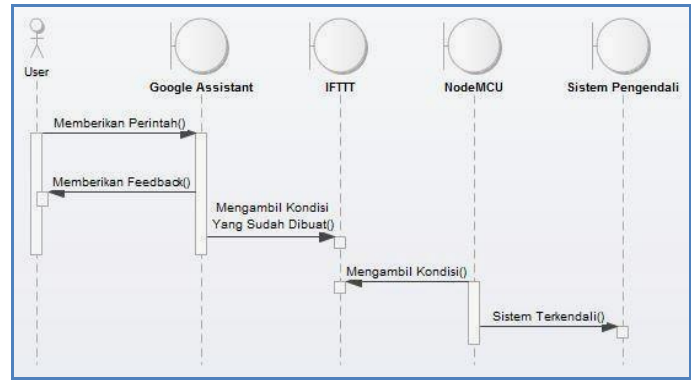

Gambar 7. Squnce Diagram Control System

Berikut Squence Diagram Control System:

a. User memberikan perintah ke google assistant.

b. Setelah google assistant menerima perintah dari user dan google assistant

c. memberikan feedback ke user.

d. IFTTT akan menggambil kondisi yang sudah dibuat sebelum nya.

e. Lalu NodeMCU akan menggambil kondisi di IFTTT, dan sistem pengendali

f. smart home terkendali.

\section{Design}

Pada langkah ini ialah mendesain alat kontrol pengendali lampu dan gerbang otomatis, yaitu pada gambar berikut:

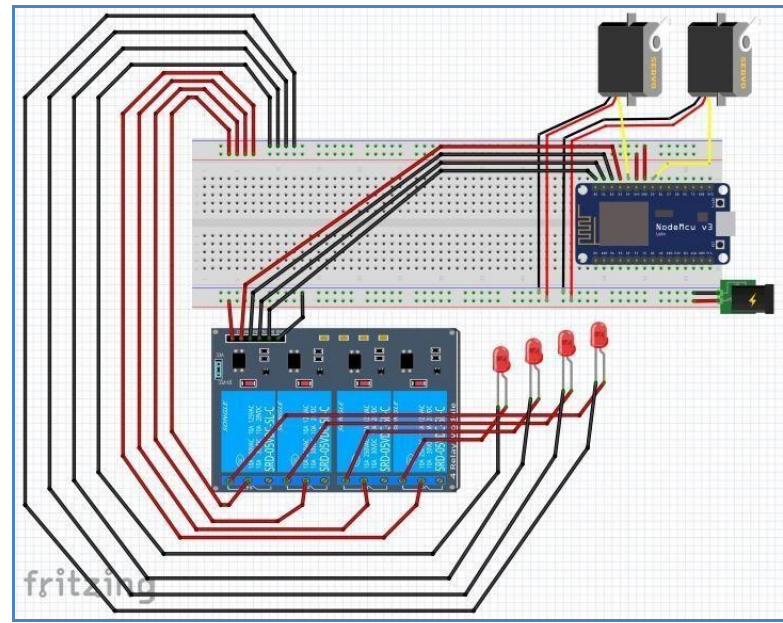

Gambar 8. Desain Alat Control

\section{Implementation}

Pada bagian ini akan digambarkan tentang implementasi prototype sistem meliputi alat pengendali lampu dan gerbang otomatis: 
Jurnal Pendidikan dan Aplikasi Industri (UNISTEK)

Vol. 8 No.1 Februari 2021

p- ISSN : $0126-4036$

e- ISSN : $2716-0416$

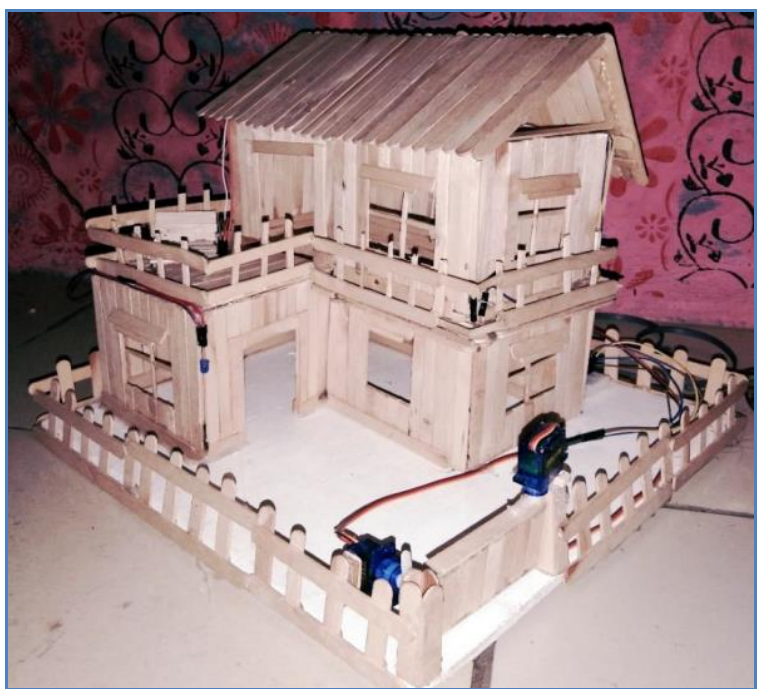

Gambar 10. Implementasi Prototipe Smart Home

\section{Sistem Pengendali Smart Home}

Penerapan sistem pengendali smart home dalam penelitian ini ialah sebagai berikut didalam Perintah user untuk menghidupkan lampu dalam, lampu luar, membuka gerbang, menutup gerbang, mengunci, dan membuka kunci gerbang.

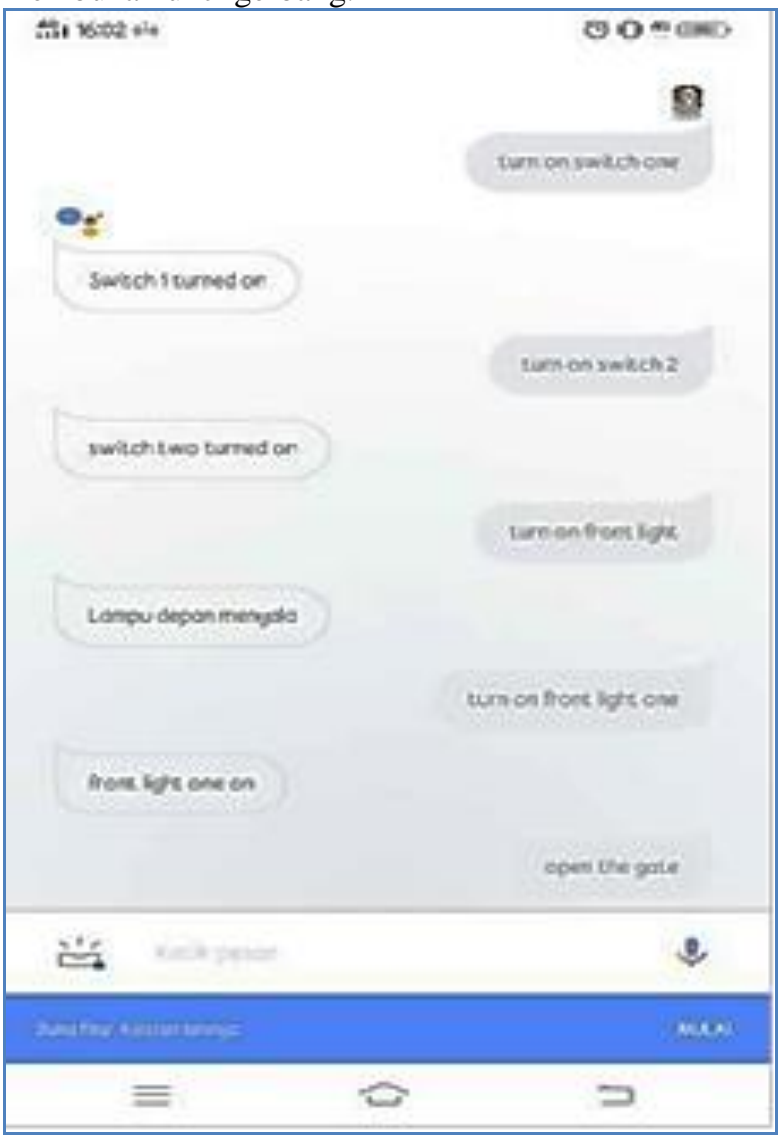

Gambar 11. Perintah Membuka/Menutup

Gerbang Dan Mengunci/Membuka Kunci Gerbang

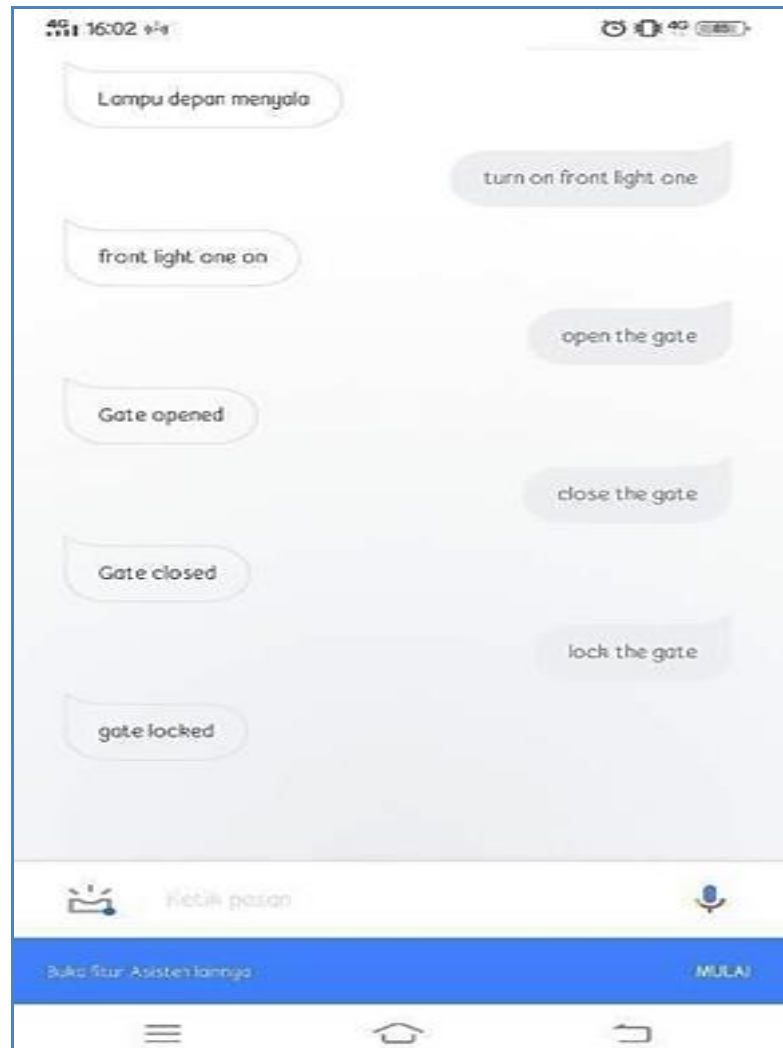

Gambar 12. Perintah Menyalakan Lampu, Menutup Gerbang, Dan Kunci Gerbang

Pengujian Validasi Delay

Berikut ini adalah tabel pengujian akurasi delay prototype sistem pengendali lampu dan gerbang otomatis

Tabel 3. Pengujian Validasi Delay

\begin{tabular}{|c|c|c|c|c|}
\hline No & Jenis Perintah & $\begin{array}{l}\text { Waktu } \\
\text { Delay }\end{array}$ & $\begin{array}{c}\text { Hasil } \\
\text { Penelitian }\end{array}$ & Validasi \\
\hline 1. & $\begin{array}{l}\text { Turn on switch one } \\
\text { (Nyalakan sakelar } \\
\text { satu) }\end{array}$ & $10 \mathrm{~ms}$ & $\begin{array}{l}\text { Lampu dalam } \\
\text { satu menyala } \\
\text { dengan waktu } \\
\text { delay } 10 \mathrm{~ms}\end{array}$ & Valid \\
\hline 2. & $\begin{array}{l}\text { Turn off switch } \\
\text { one (Matikan } \\
\text { sakelar satu) }\end{array}$ & $10 \mathrm{~ms}$ & $\begin{array}{l}\text { Lampu dalam } \\
\text { satu mati } \\
\text { dengan waktu } \\
\text { delay } 10 \mathrm{~s}\end{array}$ & Valid \\
\hline 3. & $\begin{array}{l}\text { Turn on switch two } \\
\text { (Nyalakan sakelar } \\
\text { dua) }\end{array}$ & $10 \mathrm{~ms}$ & $\begin{array}{l}\text { Lampu dalam } \\
\text { dua menyala } \\
\text { dengan waktu } \\
\text { delay } 10 \mathrm{~ms}\end{array}$ & Valid \\
\hline 4. & $\begin{array}{l}\text { Turn off switch } \\
\text { two (Matikan } \\
\text { sakelar dua) }\end{array}$ & $10 \mathrm{~ms}$ & $\begin{array}{lr}\text { Lampu } & \text { dalam } \\
\text { dua mati dengan } \\
\text { waktu delay } 10 \\
\mathrm{~ms}\end{array}$ & Valid \\
\hline 5. & $\begin{array}{l}\text { Turn on front } \\
\text { light (Nyalakan } \\
\text { lampu depan) }\end{array}$ & $10 \mathrm{~ms}$ & $\begin{array}{l}\text { Lampu luar } \\
\text { menyala dengan } \\
\text { waktu delay } 10 \\
\text { ms }\end{array}$ & Valid \\
\hline
\end{tabular}


Jurnal Pendidikan dan Aplikasi Industri (UNISTEK)

Vol. 8 No.1 Februari 2021

p- ISSN : $0126-4036$

e- ISSN : $2716-0416$

\begin{tabular}{|c|c|c|c|c|}
\hline No & Jenis Perintah & $\begin{array}{l}\text { Waktu } \\
\text { Delay }\end{array}$ & $\begin{array}{c}\text { Hasil } \\
\text { Penelitian }\end{array}$ & Validasi \\
\hline 6. & $\begin{array}{l}\text { Turn off front ligh } \\
\text { (Matikanlampu } \\
\text { depan) }\end{array}$ & $10 \mathrm{~ms}$ & $\begin{array}{l}\text { Lampu luar mati } \\
\text { dengan waktu } \\
\text { delay } 10 \mathrm{~ms}\end{array}$ & Valid \\
\hline
\end{tabular}

\begin{tabular}{llll}
\hline 7. $\begin{array}{l}\text { Turn on front } \\
\text { light one }\end{array}$ & $10 \mathrm{~ms}$ & Lampu luar satu & Valid \\
(Nyalakan lampu & & wakta dengan & \\
depan satu) & & ms & \\
\end{tabular}

\begin{tabular}{llll}
\hline 8. & Turn off front light $10 \mathrm{~ms}$ \\
one (Matikan & Lampu luar satu & Valid \\
lampu depan satu) & mati & \\
& dengan waktu & \\
& delay $10 \mathrm{~ms}$ &
\end{tabular}

\begin{tabular}{|c|c|c|c|}
\hline $\begin{array}{l}\text { 9. Turn on all } \\
\text { frontlight's } \\
\text { (Nyalakan semua } \\
\text { lampu depan) }\end{array}$ & $10 \mathrm{~ms}$ & $\begin{array}{l}\text { Semua lampu } \\
\text { luar menyala } \\
\text { dengan delay } 10 \\
\mathrm{~ms}\end{array}$ & Valid \\
\hline
\end{tabular}

\begin{tabular}{llll}
\hline $\begin{array}{l}\text { 10. Turn off all front } 10 \mathrm{~ms} \\
\text { light's (Matikan } \\
\text { semua lampu } \\
\text { depan) }\end{array}$ & $\begin{array}{l}\text { Semua lampu } \\
\text { luar mati dengan } \\
\text { delay } 10 \mathrm{~ms}\end{array}$ & Valid \\
\hline $\begin{array}{lll}\text { 11. Open the gate } \\
\text { (buka gerbang) }\end{array}$ & $15 \mathrm{~ms}$ & $\begin{array}{l}\text { Gerbang terbuka } \\
\text { dengan }\end{array}$ & Valid \\
& waktu delay 15 & \\
& ms & \\
\hline
\end{tabular}

\begin{tabular}{lll}
\hline $\begin{array}{l}\text { 12. Close the gate } \\
\text { (tutup } \\
\text { gerbang) }\end{array}$ & $15 \mathrm{~ms}$ & $\begin{array}{l}\text { Gerbang tertutup } \\
\text { dengan }\end{array}$ \\
& & Valid \\
& waktu delay 15
\end{tabular}

\begin{tabular}{|c|c|c|c|c|}
\hline 13. & $\begin{array}{l}\text { Unlock the gate } \\
\text { (buka kunci } \\
\text { gerbang) }\end{array}$ & $15 \mathrm{~ms}$ & $\begin{array}{l}\text { Kunci gerbang } \\
\text { terbuka dengan } \\
\text { waktu delay } 15 \\
\text { ms }\end{array}$ & Valid \\
\hline 14. & $\begin{array}{l}\text { Lock the gate } \\
\text { (kunci } \\
\text { gerbang) }\end{array}$ & $15 \mathrm{~ms}$ & $\begin{array}{l}\text { Gerbang } \\
\text { terkunci } \\
\text { dengan } \\
\text { waktu delay } 15 \\
\text { ms }\end{array}$ & Valid \\
\hline 15. & $\begin{array}{l}\text { Unlock the gate } \\
\text { and open the } \\
\text { gate (Buka } \\
\text { kunci gerbang } \\
\text { dan } \\
\text { buka gerbang) }\end{array}$ & $500 \mathrm{~ms}$ & $\begin{array}{l}\text { Kunci } \\
\text { gerbang } \\
\text { terbuka } \\
\text { dengan waktu } \\
\text { delay } 500 \mathrm{~ms} \\
\text { lalu gerbang } \\
\text { terbuka }\end{array}$ & Valid \\
\hline 16. & $\begin{array}{l}\text { Close the gate } \\
\text { and lock the } \\
\text { gate (tutup } \\
\text { gerbang dan } \\
\text { kunci } \\
\text { gerbang) }\end{array}$ & $500 \mathrm{~ms}$ & $\begin{array}{l}\text { Gerbang } \\
\text { tertutup } \\
\text { dengan waktu } \\
\text { delay } 500 \mathrm{~ms} \\
\text { lalu gerbang } \\
\text { terkunci }\end{array}$ & Valid \\
\hline
\end{tabular}

\section{Pengujian Menggunakan Black Box Testing}

Pengujian prototype sistem pengendali lampu dan gerbang otomatis sekolah ialah pada tabel berikut:

Tabel 3. Pengujian Black Box Testing

\begin{tabular}{|c|c|c|c|}
\hline No & $\begin{array}{l}\text { Skenario } \\
\text { Pengujian }\end{array}$ & Hasil Penelitian & Validasi \\
\hline 1. & $\begin{array}{l}\text { Membuka } \\
\text { Aplikasi } \\
\text { Google } \\
\text { Assistant }\end{array}$ & $\begin{array}{l}\text { Membuka } \\
\text { Aplikasi Google } \\
\text { Assistant Berhasil }\end{array}$ & Valid \\
\hline 2. & $\begin{array}{l}\text { NodeMCU } \\
\text { terhubung ke } \\
\text { internet }\end{array}$ & $\begin{array}{l}\text { Username } \\
\text { NodeMCU terlihat } \\
\text { di daftar hotspot }\end{array}$ & Valid \\
\hline 3. & $\begin{array}{l}\text { Memberikan } \\
\text { perintah untuk } \\
\text { menyalakan } \\
\text { lampu dalam }\end{array}$ & $\begin{array}{l}\text { Mendapatkan } \\
\text { Feedback dari } \\
\text { google assistant } \\
\text { dan lampu dalam } \\
\text { menyala }\end{array}$ & Valid \\
\hline 4. & $\begin{array}{l}\text { Memberikan } \\
\text { perintah untuk } \\
\text { mematikan } \\
\text { lampu dalam }\end{array}$ & $\begin{array}{l}\text { Mendapatkan } \\
\text { Feedback dari } \\
\text { google assistant } \\
\text { dan lampu dalam } \\
\text { mati }\end{array}$ & Valid \\
\hline 5. & $\begin{array}{l}\text { Memberikan } \\
\text { perintah untuk } \\
\text { menyalakan } \\
\text { lampu luar }\end{array}$ & $\begin{array}{l}\text { Mendapatkan } \\
\text { Feedback dari } \\
\text { google assistant } \\
\text { dan lampu luar } \\
\text { menyala }\end{array}$ & Valid \\
\hline 6. & $\begin{array}{l}\text { Memberikan } \\
\text { perintah untuk } \\
\text { mematikan } \\
\text { lampu luar }\end{array}$ & $\begin{array}{l}\text { Mendapatkan } \\
\text { Feedback dari } \\
\text { google assistant } \\
\text { dan lampu luar } \\
\text { mati }\end{array}$ & Valid \\
\hline 7. & $\begin{array}{l}\text { Memberikan } \\
\text { perintah untuk } \\
\text { menyalakan } \\
\text { lampu luar } \\
\text { secara } \\
\text { bersamaan }\end{array}$ & $\begin{array}{l}\text { Mendapatkan } \\
\text { Feedback dari } \\
\text { google assistant } \\
\text { dan lampu luar } \\
\text { menyala secara } \\
\text { bersamaan }\end{array}$ & Valid \\
\hline 8. & $\begin{array}{l}\text { Memberikan } \\
\text { perintah untuk } \\
\text { mematikan } \\
\text { lampu luar } \\
\text { secara } \\
\text { bersamaan }\end{array}$ & $\begin{array}{l}\text { Mendapatkan } \\
\text { Feedback dari } \\
\text { google assistant } \\
\text { dan lampu luar } \\
\text { mati bersamaan }\end{array}$ & Valid \\
\hline 9. & $\begin{array}{l}\text { Memberikan } \\
\text { perintah untuk } \\
\text { membuka } \\
\text { gerbang }\end{array}$ & $\begin{array}{l}\text { Mendapatkan } \\
\text { Feedback dari } \\
\text { google assistant } \\
\text { dan } \\
\text { terbuka }\end{array}$ & Valid \\
\hline 10. & $\begin{array}{l}\text { Memberikan } \\
\text { perintah untuk } \\
\text { menutup } \\
\text { gerbang }\end{array}$ & \begin{tabular}{l}
\multicolumn{2}{l}{ Mendapatkan } \\
Feedback dari \\
google assistant \\
dan \\
tertutup
\end{tabular} & Valid \\
\hline 11. & $\begin{array}{l}\text { Memberikan } \\
\text { perintah untuk } \\
\text { mengunci } \\
\text { gerbang }\end{array}$ & $\begin{array}{l}\text { Mendapatkan } \\
\text { Feedback dari } \\
\text { google } \\
\text { dan } \\
\text { terksistant } \\
\end{array}$ & Valid \\
\hline 12. & $\begin{array}{l}\text { Memberikan } \\
\text { perintah untuk } \\
\text { membuka } \\
\text { kunci gerbang }\end{array}$ & $\begin{array}{l}\text { Mendapatkan } \\
\text { Feedback dari } \\
\text { google assistant } \\
\text { dan kunci gerbang } \\
\text { terbuka }\end{array}$ & Valid \\
\hline 13. & $\begin{array}{l}\text { Memberikan } \\
\text { perintah utuk }\end{array}$ & $\begin{array}{l}\text { Mendapatkan } \\
\text { Feedback dari }\end{array}$ & Valid \\
\hline
\end{tabular}




\begin{tabular}{|c|c|c|c|}
\hline No & $\begin{array}{c}\text { Skenario } \\
\text { Pengujian }\end{array}$ & Hasil Penelitian & Validasi \\
\hline & $\begin{array}{ll}\text { membuka } & \\
\text { kunci lalu } \\
\text { membuka } \\
\text { gerbang }\end{array}$ & $\begin{array}{lr}\text { google assistant } \\
\text { dan kunci gerbang } \\
\text { terbuka lalu } \\
\text { gerbang terbuka }\end{array}$ & \\
\hline 14. & $\begin{array}{l}\text { Memberikan } \\
\text { perintah untuk } \\
\text { menutup } \\
\text { gerbang lalu } \\
\text { mengunci } \\
\text { gerbang }\end{array}$ & $\begin{array}{l}\text { Mendapatkan } \\
\text { Feedback dari } \\
\text { google assistant } \\
\text { dan gerbang } \\
\text { terbuka } \quad \text { lalu } \\
\text { gerbang terkunci }\end{array}$ & Valid \\
\hline
\end{tabular}

Dari hasil penelitian berikut bahwasanya prototype smart home mengendali lampu dan dan gerbang otomatis berbasis Internet of Thing dengan menggunakan aplikasi google asisstent dapat diterapkan di Sekolah Islam Pelita Insan, sehingga pekerjaan penjaga sekolah menjadi lebih efektif, efisien dan lebih aman.

\section{Kesimpulan}

Dari hasil penelitian ini berupa prototype smart home pengendali lampu dan gerbang otomatis berbasis IoT (Internet of Things) hingga proses pengujian dapat diambil kesimpulan yaitu: dengan adanya prototipe sistem pengendali lampu dan gerbang otomatis ini diharapkan dapat memudahkan, efisien dan efektif untuk pengelola dan penjaga sekolah dalam penggunaan perangkat elektronik seperti lampu serta gerbang sekolah berbasis Internet of Things dengan cara memberikan perintah ke google assistant yang terkoneksi ke Microcontroller NodeMCU V3, sehingga dapat menghemat pemakaian energi listrik dan keamanan sekolah lebih terjaga.

\section{Saran}

Dalam penelitian ini penulis memberikan saran untuk peneliti-peneliti selanjutnya dalam pengembangan sistem monitoring pengendali mesin, elektronik dan yang lainnya yang berbasis smart home berbasis Internet of Things ialah sebagai berikut:

1. Untuk pengembangan sistem selanjutnya dapat di lengkapi dengan sistem pengendali alat-alat elektronik yang lain sehingga bisa lebih mempermudah lagi untuk pengelola dan penjaga sekolah.

2. Perancangan ini dapat dijadikan acuan dalam pengembangan sistem lainnya, seperti otomatisasi lampu jalan, portal otomatis, dan pintu rumah otomatis.

3. Untuk pengembangan lebih lanjut dapat di tambahkan database seperti adanya laporan saat lampu atau peralatan leketronik di hidupkan atau di matikan dan saat gerbang di buka atau ditutup.

\section{Daftar Pustaka}

Booch, G., Rumbaugh, J., \& Jacobson, I. (2013). The Unifiled Modeling Language User Guide
Second Edition, vol. Vol 6 No.1, Addison Wesley, pp. 5-15.

Briere, D., \& Hurley, P. (2007). Smart Homes for Dummies. Canada: Wiley Publishing, Inc.

Hassan, Q. F., Khan, A. u., \& Madani, S. A. (2018). Internet of Things Challenges, Advances, and Applications. New York: CRC Press.

McLeod, Raymond, and George, P., Schell. (2008). "Management Information System", $10^{\text {th }}$ ed. Dialihbahasakan oleh Yulianto, A, Akbar dan Afia, R, Fitriati. Jakarta: Salemba Empat.

Nussey, J., (2013). "Arduino for dummies," dalam Arduino for dummies, England, John Wiley \& Sons, Ltd, p. 1st ed.

Sasongko, H.B., (2012). Pemrograman Mikrokontroler Dengan Bahasa C, Yogyakarta: Andi Offset.

Satriadi, A., Wahyudi, \& Christiyono, Y. (2019). Perancangan Home Automation Berbasis NodeMCU. Transient, 8(1), 64-71. 
Jurnal Pendidikan dan Aplikasi Industri (UNISTEK)

Vol. 8 No.1 Februari 2021

p- ISSN : 0126 - 4036

e- ISSN : $2716-0416$ 